\title{
A laboratory study to evaluate the toxicity of the Mediterranean fruit fly, Ceratitis capitata, bait, Success 0.02 CB, to the honey bee, Apis mellifera ${ }^{1}$
}

\author{
C. Richard Edwards*, Corey K. GERber, Greg J. Hunt \\ Department of Entomology, Purdue University, West Lafayette, IN 47907-1158, USA
}

(Received 21 June 2002; revised 21 August 2002; accepted 17 September 2002)

\begin{abstract}
USDA APHIS and Moscamed have developed an eradication program for the Mediterranean fruit fly, Ceratitis capitata (Wiedemann), in North and Central America. Currently, the primary chemical used to control fruit flies in Central America is spinosad, Success $0.02 \mathrm{CB}^{\mathrm{TM}}$ (GF-120). Central America, and Guatemala in particular, has a thriving apiculture industry. Many Guatemalan beekeepers believe that Success is toxic to honey bees, Apis mellifera L., and that its use has resulted in a decrease in bee populations and subsequent honey production. Continuous, limited, and topical exposure studies demonstrated that Success is toxic to honey bees at varying levels, depending upon exposure and drying time, as demonstrated by $24 \mathrm{~h}$ bioassays. Future studies should evaluate the effects of Success in the field on foraging honey bees and brood health during a season long Medfly control program to determine possible honeybee impacts.
\end{abstract}

Apis mellifera / Ceratitis capitata / spinosad / Success 0.02 CB / toxicity / apiculture

\section{INTRODUCTION}

The Mediterranean fruit fly (Medfly), Ceratitis capitata (Wiedemann) (Diptera, Tephritidae), is considered to be one of the most destructive pests of fruits and vegetables worldwide. Currently, the host range of the Medfly covers more than 350 different fruit and vegetable crops (Liquido et al., 1991). It is believed that the Medfly originated in Africa and has since spread into the Americas, southern Europe, Mediterranean region, Middle East, western Australia, and Hawaii (USDA APHIS, 1999).

In 1955, the Medfly was first introduced into Central America and by the mid-1970s spread into Mexico (USDA APHIS, 2001).
Based on the potential magnitude of damage caused by this pest, the United States Department of Agriculture (USDA) Animal and Plant Health Inspection Service (APHIS) developed an extensive eradication program for the Medfly in North and Central America. Known as the Moscamed (Spanish for Medfly) program, this cooperative program among the USA, Mexico, and Guatemala is not only designed to protect USA, Mexican, and Guatemalan fruit and vegetable production, but also to promote crops for export from Mexico and Guatemala to the USA and European markets. In Guatemala, the main area of Medfly control with insecticide baits is in coffee producing areas where coffee serves as an excellent host for Medfly populations, of

\footnotetext{
${ }^{1}$ Mention of commercial products in this publication is solely for the purpose of reporting research findings and does not imply a recommendation, endorsement, or discommendation by Purdue University.

* Correspondence and reprints

E-mail: rich_edwards@entm.purdue.edu
} 
which a significant proportion of these populations also attack other crops (Thompson, personal communication).

Eradication techniques used in the Moscamed program include the release of sterile males, as well as cultural, regulatory, and chemical control tactics (USDA APHIS, 2001). An aerially applied malathion-bait was the initial insecticide used in the Moscamed program (Villaseñor et al., 2000). In the USA, malathion-bait sprays have been extensively used in Medfly control programs since 1956 (Steiner et al., 1961; Ehler et al., 1984; Phillips, 1995). Malathion is highly toxic to a number of hymenopterous insects, such as the honey bee, Apis mellifera L. (Levin et al., 1968; Gary and Mussen, 1984; Pankiw and Jay, 1992), and various parasitoids (Hoy and Dahlsten, 1984; Cohen et al., 1987; Daane et al., 1990; Hoelmer and Dahlsten, 1993). Due to its broad spectrum toxicity characteristic, malathion aerial bait sprays have been prohibited in Guatemala since 1987 (Villaseñor et al., 2000). Currently, spinosad, a derivative of the naturally occurring actinomycete Saccharopolyspora spinosa (Dow AgroSciences, 2001), combined with ammonium acetate, an efficacious fruit fly attractant commonly used in monitoring programs (Heath et al., 1997; Epsky et al., 1999; Katsoyannos et al., 1999), as well as a honey bee repellant (USDA APHIS, 2001), has been formulated and labeled as Success 0.02 CB $^{\mathrm{TM}}$ (GF-120). Studies show that Success is highly efficacious in the control of fruit flies and relatively safe to hymenopterous insects (Peck and McQuate, 2000; Burns et al., 2001; Vargas et al., 2001). Therefore, Success has recently been used in the Moscamed program in Guatemala as an alternative to malathion (USDA APHIS, 2001).

Central America, and Guatemala in particular, has a thriving apiculture industry supplying honey to domestic and international markets. Almost from the start of the Guatemalan Medfly spray program in the early 1980s, beekeepers have observed and complained that areas sprayed with malathion (Villaseñor et al., 2000), and more recently Success (el Periódico, 2002), have experienced a decline in honey bee numbers, as well as a decrease in overall honey production. Several studies conducted by government, industry, and private groups on the specific impact of Success on honey bees have shown negligible effects, especially in situations where the product has dried prior to honey bee exposure (Rendon et al., 2000; Dow AgroSciences, 2001). Some researchers believe that the real problem is not related to Success, but to the impact of Varroa destructor mites and different diseases on bee health (Prensa Libre, 2001). Yet, many Guatemalan beekeepers are convinced that Success is killing honey bees (el Periódico, 2002). This carries an even greater significance in coffee producing regions due to the findings presented in a recent paper showing that honey bees can increase coffee bean yields by more than $50 \%$ (Roubik, 2002). Previously it was thought that yield in self-pollinated coffee was not significantly affected by pollinating insects.

The objective of this study was to determine if wet and/or dry residues of Success affect honey bees under laboratory conditions at the rate used for Medfly control in Guatemala.

\section{MATERIALS AND METHODS}

Three studies to determine if Success is toxic to honey bees were developed in 2001: continuous exposure, limited exposure, and topical exposure. For these studies, honey bees were collected directly from the outer combs of honey bee colonies at the Purdue Apiary, West Lafayette, Indiana.

In the laboratory, honey bees were held at $\approx 24{ }^{\circ} \mathrm{C}$ under ambient florescent lighting until placed into a $-1.0^{\circ} \mathrm{C}$ freezer for cool-down prior to being transferred to $150 \times 25 \mathrm{~mm}$ clear plastic petri dishes for the continuous exposure and limited exposure studies, and into $95 \times 25 \mathrm{~mm}$ clear plastic petri dishes for the topical exposure study. The dishes, with 4 and 5 ventilation holes placed in the sides and lids, respectively, were positioned on a bench top covered with white craft paper. One triangular piece $\left(13.30 \mathrm{~cm}^{3}\right)$ of an artificial sponge saturated with a $50 \%$ sucrose solution was placed against the wall of each dish, whether treated or not, and served as a source of food and water for the bees.

\subsection{Continuous exposure study}

In the continuous exposure study, two treatments of Success, the recommended rate $[1 \times$ rate (1 part Success: 1.5 parts $\mathrm{H}_{2} \mathrm{O}$ )] and $10 \times$ rate 
(10 parts Success: 1.5 parts $\mathrm{H}_{2} \mathrm{O}$ ), were used. A $15 \mu \mathrm{L}$ droplet [recommended range of droplet size in the field $(\approx 4 \mathrm{~mm}$ diameter $)]$ of either the $1 \times$ or $10 \times$ rate was placed in the center of each dish. Once the droplets dried for either 6 or $24 \mathrm{~h}$, eight honey bees were placed into each dish. In addition, wet residue treatments of Success at the $1 \times$ and $10 \times$ rate were also included in the study. In the wet residue treatments, eight honey bees were placed into each dish prior to the introduction of a Success $15 \mu \mathrm{L}$ droplet. Control treatments consisted of only an artificial sponge saturated with the 50\% sucrose solution and eight honey bees. There were six replications per treatment. Honey bee mortality was recorded at 6,12 , and $24 \mathrm{~h}$ post-exposure to each treatment.

\subsection{Limited exposure study}

This study was initiated based on the results obtained in the continuous exposure study. Since honey bees in the continuous exposure study experienced a worse-case exposure situation, it was decided that a study designed to mimic the more natural situation of 1 to $3 \mathrm{~h}$ of possible exposure by foraging honey bees in the Medfly managed area would be conducted.

A Success $1 \times$ rate $(1$ part Success: 1.5 parts $\mathrm{H}_{2} \mathrm{O}$ ) and a $95 \%$ malathion+Nu-lure ${ }^{\circledR} 1 \times$ rate (1 part 95\% malathion: 4 parts Nu-lure) were used in the limited exposure study. Nu-lure is a protein bait used for attracting fruit flies. A $15 \mu \mathrm{L}$ droplet $(\approx 4 \mathrm{~mm}$ diameter $)$ of either Success or malathion+Nu-lure was placed in the center of each dish, and after these droplets dried for $\approx 6 \mathrm{~h}$, six honey bees were placed into each dish. These represented the dry treatments. Wet treatments consisted of the same dilutions of Success and malathion+Nu-lure, but prior to the $15 \mu \mathrm{L}$ droplets being placed in the dishes, six honey bees were transferred into these testing dishes. Next, a droplet of either Success or malathion+Nu-lure was placed in the center of each dish. Control treatments consisted of only an artificial sponge saturated with the $50 \%$ sucrose solution and six honey bees. Each treatment was replicated six times.

In one half of the treatment dishes, which represented all treatments (dry, wet, and control) and where the bees had been exposed for $1 \mathrm{~h}$ to the insecticide treatments or to the untreated dishes, the bees were removed and placed into non-insecticide treated dishes. The honey bees in the remaining dishes were removed and placed into noninsecticide treated dishes after an exposure time of $3 \mathrm{~h}$. Honey bee mortality was recorded at $1,6,12$, and $24 \mathrm{~h}$ after being place into the non-insecticide treated dishes.

\subsection{Topical exposure study}

Two dilutions of Success, $1 \times(1$ part Success: 1.5 parts $\left.\mathrm{H}_{2} \mathrm{O}\right)$ and $0.1 \times(0.1$ part Success: 1.5 parts $\mathrm{H}_{2} \mathrm{O}$ ) and two dilutions of $95 \%$ malathion+Nu-lure, $1 \times(1$ part 95\% malathion: 4 parts Nu-lure $)$ and $0.1 \times(0.1$ part $95 \%$ malathion: 4 parts $\mathrm{Nu}$-lure $)$ were included in the topical exposure study. A $50 \%$ sucrose solution treatment and a control treatment were also included. Excluding the control treatment, a $10 \mu \mathrm{L}$ droplet $(\approx 3 \mathrm{~mm}$ diameter) of either the Success $1 \times$ or $0.1 \times$ rate, the malathion+Nu-lure $1 \times$ or $0.1 \times$ rate, or the $50 \%$ sucrose solution, was placed on the dorsal surface of the thorax of each honey bee in each of the respective treatments. One honey bee was placed into each dish. Each treatment was replicated 10 times. Honey bee mortality was recorded at 1,3 , 6 , and $12 \mathrm{~h}$ post-exposure to each selected treatment.

\subsection{Statistical analyses}

Arcsine transformations were performed for each test to normalize percentage mortality data. Transformed data were analyzed using one factor ANOVA procedures, and mean separations were made using Fisher's protected least significant difference test $(P \leq 0.05)$ (SuperANOVA, 1989). In graphs, percentage bee mortality data, without transformations, were presented.

\section{RESULTS}

\subsection{Continuous exposure study}

At $6 \mathrm{~h}$ after exposure, significantly more honey bees died in the Success $1 \times 6 \mathrm{~h}$ dry treatment $(43.8 \%)$ than in the dishes that contained the $1 \times 24 \mathrm{~h}$ dry treatment $(4.2 \%)$ (Fig. 1A). We assumed that higher mortality would occur with the wet residue treatments as compared to the dry treatments. This assumption was based on the fact that wet residues are more easily taken up via ingestion or penetration through the cuticle of an insect, when direct contact occurs. Although not statistically different from the $1 \times 6 \mathrm{~h}$ dry treatment, numerically fewer honey bees died in the wet treatments $(1 \times$ wet: $27.1 \%, 10 \times$ wet: $35.4 \%$ ). Based on these data, we believe that the wet residue repelled the honey bees, reducing the chances of direct contact with the Success droplet. This is in agreement with 

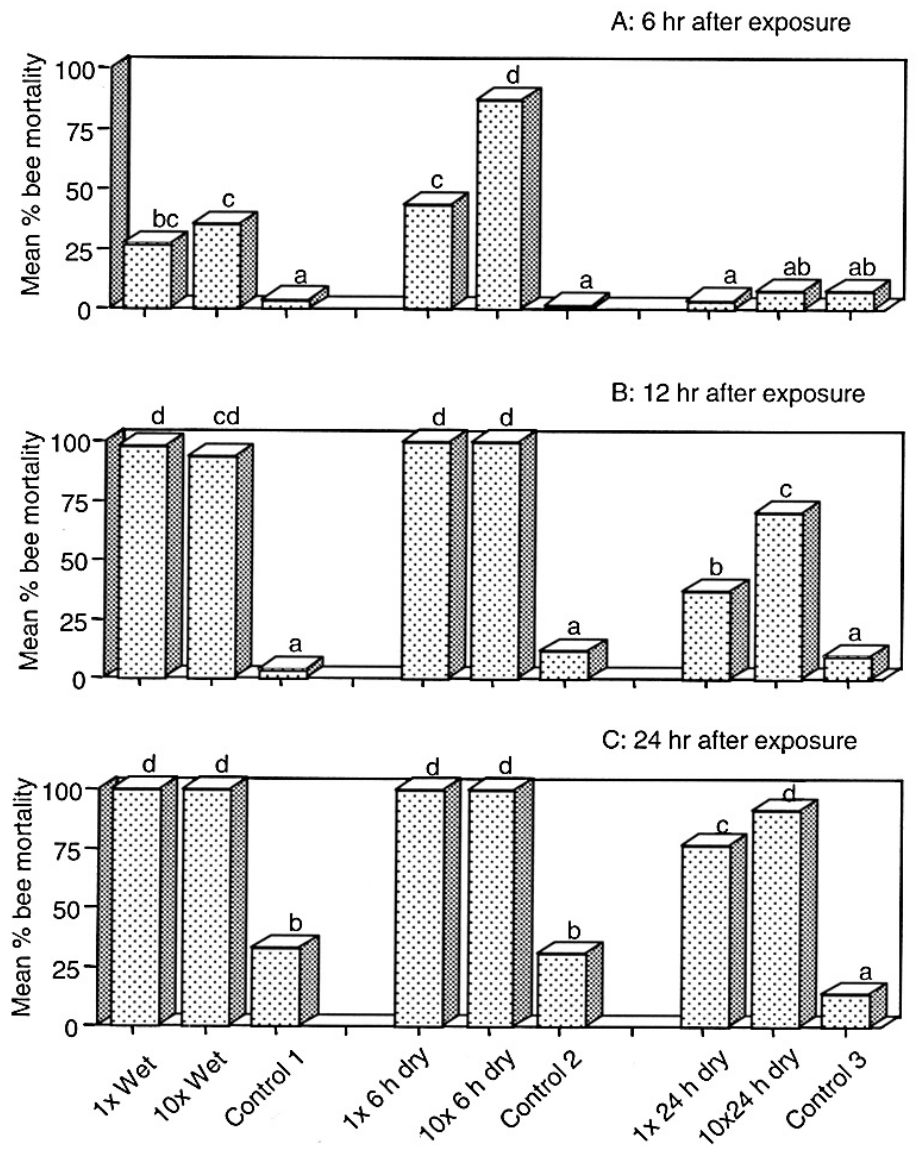

Figure 1. A-C. Honey bee mean mortality $(\%)$ after 6,12 , and $24 \mathrm{~h}$ of exposure to either $1 \times$ or $10 \times$ rates of Success $0.02 \mathrm{CB}$ (wet residue, $6 \mathrm{~h}$ and $24 \mathrm{~h}$ dried residues). Bars with the same letter(s) are not significantly different at $P \leq 0.05$.

information supplied by Dow AgroSciences (Thompson, personal communication).

After $12 \mathrm{~h}$ post exposure, $100 \%$ bee mortality was recorded for the Success $1 \times$ and $10 \times$ $6 \mathrm{~h}$ dry treatments (Fig. 1B). Taking into account control mortality (12.5\%), Success was responsible for $87.5 \%$ of the bee mortality. When individual treatments were compared using a one factor ANOVA (Fig. 1B), the wet treatments were not significantly different than the Success $1 \times$ and $10 \times 6 \mathrm{~h}$ dry treatments. We believe that the wet treatments, after drying naturally over time, resulted in reduced repellency and therefore increased the chances of honey bees coming into contact with the residue, which resulted in a higher percentage mortality. Bee mortality in the Success $1 \times 24 \mathrm{~h}$ dry treatment was significantly less than both the Success wet and $6 \mathrm{~h}$ dry treatments, but the Success $1 \times 24$ h dry treatment still accounted for $27.1 \%$ (difference between Success $1 \times 24$ h dry treatment minus control 3) of the bee mortality.

At $24 \mathrm{~h}$ after exposure, the Success $1 \times$ and $10 \times$ wet and $6 \mathrm{~h}$ dry treatments, after $24 \mathrm{~h}$ of exposure, $100 \%$ of the bees died, compared to the mean of $33.3 \%$ in control 1 and $31.3 \%$ in control 2 (Fig. 1C). Therefore, 66.7\% and $68.7 \%$ of the bee mortality was attributed to the Success $1 \times$ and $10 \times$ wet and 6 h dry treatments, respectively. However, when the Success $1 \times$ rate was allowed to dry for $24 \mathrm{~h}$, the 

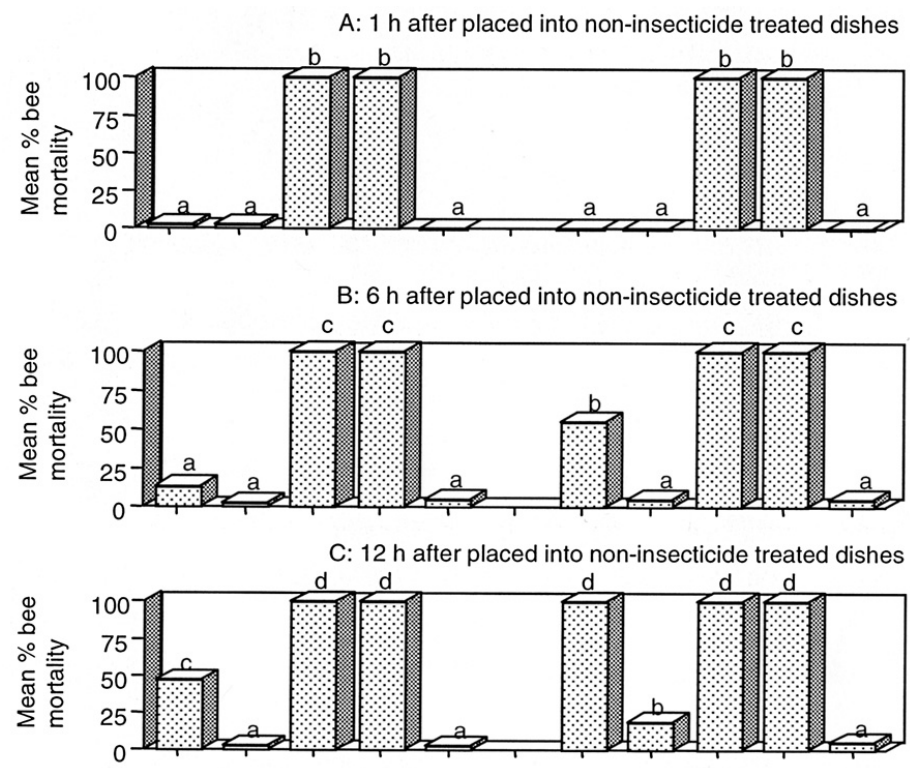

D: $24 \mathrm{~h}$ after placed into non-insecticide treated dishes

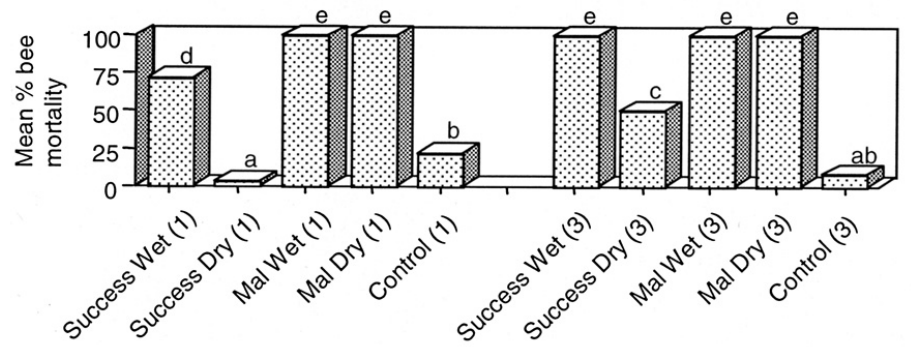

Figure 2. A-D. Honey bee mean mortality (\%) after 1, 6, 12, and $24 \mathrm{~h}$ of being placed into non-insecticide treated dishes following either 1 or $3 \mathrm{~h}$ exposure to wet or dry residues of either Success $0.02 \mathrm{CB}$ or malathion $+\mathrm{Nu}$-lure. Bars with the same letter(s) are not significantly different at $P \leq 0.05$.

level of bee mortality was significantly lower than when allowed to dry for $6 \mathrm{~h}$ (Fig. 1C). Hence, after $24 \mathrm{~h}$ of exposure to the $24 \mathrm{~h}$ dried residue treatment, $77.1 \%$ of the bee mortality occurred at the Success $1 \times$ rate as compared to the $14.6 \%$ in the control treatment. Therefore, $62.5 \%$ of the bee mortality was attributed to Success. Although there was a statistical difference between bee mortality percentages at the Success $1 \times 6 \mathrm{~h}$ dry treatment and the $1 \times$ $24 \mathrm{~h}$ dry treatment, after the honey bees were exposed for $24 \mathrm{~h}$, numerically there was only a $22.9 \%$ difference between these figures when percentage mortality was compared. By comparing the true mortality (difference between Success $1 \times 6 \mathrm{~h}$ dry treatment minus control 2 and Success $1 \times 24 \mathrm{~h}$ dry treatment minus control 3), there was a $6.3 \%$ numerical difference of bee mortality between the 6 and $24 \mathrm{~h}$ dry residue treatments.

\subsection{Limited exposure study}

The malathion residue treatments at both the 1 and $3 \mathrm{~h}$ initial exposure times showed $100 \%$ bee mortality after $1 \mathrm{~h}$ in non-insecticide treated dishes (Fig. 2A). Bee mortality recorded during this same time period for the Success and control treatments was not statistically different from each other and ranged from $0-2.8 \%$ (Fig. 2A). 
When bee mortality was recorded after $6 \mathrm{~h}$ in the non-insecticide treated dishes, honey bee mortality was $55.6 \%$ after being initially exposed for $3 \mathrm{~h}$ to the Success wet treatment (Fig. 2B). This, however, was significantly less than the mortality (100\%) in the malathion treatments, but statistically higher than bee mortality recorded in the Success wet $(13.9 \%)$ and dry $(2.8 \%) 1 \mathrm{~h}$ exposure treatments, the Success dry $3 \mathrm{~h}$ exposure treatment $(5.5 \%)$, and both controls (5.6\% and 5.5\%) (Fig. 2B). After $12 \mathrm{~h}$ of being in the non-insecticide treated dishes, all honey bees initially exposed for $3 \mathrm{~h}$ to the Success wet residues were dead (Fig. 2C). Honey bee mortality increased from $13.9 \%$ to $47.2 \%$, over a $6 \mathrm{~h}$ time frame, in the Success wet treatment where the bees were exposed initially for $1 \mathrm{~h}$ (Figs. 2B and 2C).

When bee mortality was recorded after $24 \mathrm{~h}$ of the honey bees being placed into the noninsecticide treated dishes, for the Success dry residue treatment where the bees were exposed initially for $1 \mathrm{~h}$, the bee mortality level was not statistically different from control exposed for $3 \mathrm{~h}(8.3 \%)$, and was statistically lower than the other control treatment (22.2\%) (Fig. 2D). Mortality of honey bees initially exposed to the Success dry treatment for $3 \mathrm{~h}$ was statistically higher than the control treatments, and resulted in $50.0 \%$ mortality. Under these conditions, $34.7 \%$ of the bee mortality was attributed to Success when it dried for $6 \mathrm{~h}$ and the bees were exposed initially to the chemical residue for 3 h (Fig. 2D).

\subsection{Topical exposure study}

One $\mathrm{h}$ after the malathion $+\mathrm{Nu}$-lure $1 \times$ and $0.1 \times$ treatments came into direct contact with the honey bees, $100 \%$ bee mortality was recorded. No bee mortality was noted after $1 \mathrm{~h}$ for the two rates of Success, sucrose solution, and control (Fig. 3A).

When bee mortality was recorded after a $3 \mathrm{~h}$ exposure, bee mortality in the Success $1 \times$ treatment was significantly less $(50 \%)$ than the mortality $(100 \%)$ in the malathion treatments, but statistically higher than bee mortality in the Success $0.1 \times(10 \%)$, sucrose solution $(0 \%)$ and control $(0 \%)$ treatments (Fig. 3B).
However, after $6 \mathrm{~h}$ of exposure, the Success $1 \times$ treatment was not significantly different from the malathion treatments. The sucrose solution and control treatments were not significantly different from each other for this period of exposure, but were significantly different from the chemical treatments (Fig. 3C).

After $12 \mathrm{~h}$ of exposure, $100 \%$ bee mortality occurred at both rates of malathion and Success. Thirty percent bee mortality was recorded in the control treatment. Therefore, $70 \%$ of the bee mortality was attributed to each of the malathion and Success treatments (Fig. 3D).

\section{DISCUSSION}

Based on the topical exposure study results, Success applied when honey bees are foraging can result in bee mortality, if the wet product comes into direct contact with the honey bees. However, Success treatments are normally applied during hours when honey bees are not actively foraging, thus reducing the risk of direct exposure to the wet product. According to previous studies (Rendon et al., 2000; Dow AgroSciences, 2001), dried product is less toxic to honey bees than wet product. Although these previous studies showed that dried Success residues are "not toxic" to bees, our continuous and limited exposure studies demonstrated otherwise. It was shown that dry Success residues were less toxic than wet Success and malathion residues; however, bee mortality still occurred with dried $1 \times$ rates of Success. There have been reports that the Success is a honey bee repellant (USDA APHIS, 2001). We observed that it has repellant qualities when wet, but bees were observed feeding on dried Success residues (residues that dried for $3 \mathrm{~h}$ prior to bee introductions).

If Success dried for $6 \mathrm{~h}$ and bees were exposed for $1 \mathrm{~h}$ to the dried residue, no increase in bee mortality was observed when compared to the control treatment. However, if the honey bees were exposed for $3 \mathrm{~h}, \approx 50 \%$ mortality occurred. It is not unusual for bees to forage $0.5 \mathrm{~h}$ or more and to make $\approx 10$ foraging trips per day (Gary, 1992). Therefore, honey bees can experience an accumulative exposure 

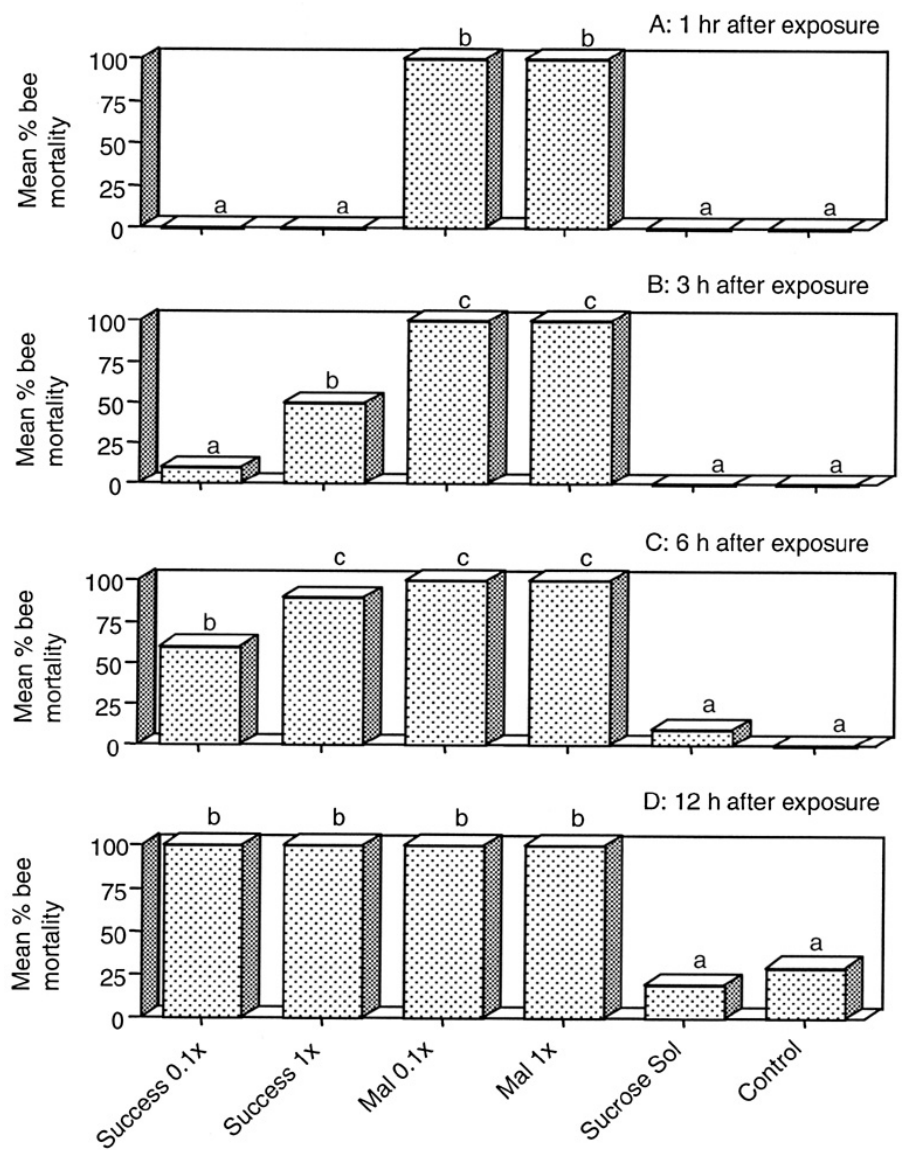

Figure 3. A-D. Honey bee mean mortality (\%) after $1,3,6$, and $12 \mathrm{~h}$ of exposure to either $0.1 \times$ or $1 \times$ rates of Success $0.02 \mathrm{CB}$ or malathion $+\mathrm{Nu}$-lure, or a $1 \times$ rate of $50 \%$ sucrose solution. Bars with the same letter(s) are not significantly different at $P \leq 0.05$.

of several hours to Success during a $24 \mathrm{~h}$ foraging period. With repeated sprays of Success over a Medfly control season, longterm effects on honey bees and hive health are possible.

It is our recommendation that this product be further evaluated for its impact on foraging honey bees where Success is applied over an entire Medfly control season and that hive health in the Medfly managed area be monitored and compared to hives in untreated areas within the same region. Also, hives should be evaluated for the presence and possible impact of Varroa destructor mites and honey bee diseases since some believe that these pose an additional threat to honey bees.

\section{ACKNOWLEDGEMENTS}

We thank the United States Agency for International Development (USAID) Integrated Pest Management (IPM) Collaborative Research Support Program (CRSP) for providing the opportunity to address this issue and to make contacts with those involved in the Moscamed program or impacted by it. Special thanks to Karina Illescas, IPM CRSP Guatemala, for supplying the bee articles from Guatemalan newspapers and Carlos Mayen, IPM CRSP Graduate Student, for translating these and other important information from Spanish into English. We also thank Gary Thompson, Dow AgroSciences, for providing product, reference material, personal communications, and dilution information on Success $0.02 \mathrm{CB}$, malathion, and Nu-lure. This is Purdue Agricultural Research Programs Paper No. 16799 
Résumé - Étude au laboratoire pour évaluer la toxicité vis-à-vis de l'Abeille domestique, Apis mellifera, de Success 0.02 CB, attractif de la Mouche méditerranéenne des fruits, Ceratitis capitata. Dans le monde entier la Mouche méditerranéenne des fruits (MMF), Ceratitis capitata (Wiedemann) (Diptera, Tephritidae), est l'un des ravageurs les plus sérieux des cultures fruitières et légumières. En raison du potentiel de dégâts aux cultures, le Département de l'Agriculture des États-Unis (USDA) et le Service d'Inspection de la Santé des Plantes et des Animaux (APHIS), en collaboration avec les gouvernements du Mexique et du Guatemala, ont mis en œuvre un programme extensif d'éradication de la MMF. Le produit Success $0.02 \mathrm{CB}^{\mathrm{TM}}$, une combinaison de spinosad et d'acétate d'ammonium attracticide pour la MMF et répulsive pour l'Abeille, est actuellement le principal produit de lutte utilisé dans le programme d'éradication. Le Guatemala a une industrie apicole florissante et, pratiquement dès le début du programme d'éradication, les apiculteurs se sont plaints d'un déclin des populations d'abeilles ainsi que d'une diminution de la production globale de miel dans les zones traitées au Success. Certains chercheurs pensent que le problème ne vient pas de Success mais de l'acarien Varroa destructor et de différentes maladies des abeilles. Le but de cette étude était de déterminer par des études de laboratoire si la dose de Success, telle qu'appliquée dans la lutte contre la MMF, tuait les abeilles.

Des études d'exposition continue (EC), limitée (EL) et topique (ET) d'abeilles à des résidus de Success ont été menées dans des conditions de laboratoire à l'université de Purdue, West Lafayette (Indiana, USA) en 2001. Pour réduire la mortalité naturelle par manque de nourriture, une éponge saturée d'une solution de saccharose à $50 \%$ a été placée dans chaque récipient de test. Dans l'étude $\mathrm{EC}$, les abeilles ont été mises en présence d'une goutte de $15 \mu \mathrm{L}$ de résidus humides ou secs (résidus séchés durant 6 ou $24 \mathrm{~h}$ ) de la dose ou de 10 fois la dose recommandée. La mortalité a été enregistrée 6, 12 et $24 \mathrm{~h}$ après l'exposition. Dans l'étude EL les abeilles ont été mises en présence d'une goutte de $15 \mu \mathrm{L}$ de résidus humides ou secs (résidus séchés durant 6) d'une dose de Success ou d'une dose de $95 \%$ malathion+Nu-lure ${ }^{\circledR}$ durant 1 ou $3 \mathrm{~h}$. Les abeilles ont été ensuite placées dans des boîtes de Pétri non traitées à l'insecticide et la mortalité a été enregistrée 1, 6, 12 ou 24 h plus tard. Dans l'étude ET, une goutte de $10 \mu \mathrm{L}$ d'une dose ou de 0,1 dose soit de Success, soit de de $95 \%$ malathion+Nu-lure, soit d'une solution de saccharose à $50 \%$ a été déposée directement sur les abeilles. La mortalité a été enregistrée $1,3,6$ et $12 \mathrm{~h}$ plus tard.

Les résultats de l'étude EC montrent qu'un traitement avec une dose de Success qu'on laisse sécher $6 \mathrm{~h}$ et auquel les abeilles sont exposées $6 \mathrm{~h}$ est responsable d'une mortalité d'abeilles de $43,8 \%$. Lorsqu' on laisse sécher le traitement 24 h, il n'y a plus que $4,2 \%$ de mortalité après une exposition de $6 \mathrm{~h}$; néanmoins, après une exposition de $24 \mathrm{~h}$, le traitement est responsable d'une mortalité de $62,5 \%$. Dans l'étude EL, si les abeilles ne sont pas exposées plus d'une heure au traitement séché d'une dose de Success, il n'y a pas de différence dans la mortalité des abeilles avec le traitement témoin lorsqu'on laisse les abeilles $12 \mathrm{~h}$ dans les boites non traitées. Néanmoins pour une exposition de $3 \mathrm{~h}$ au résidu sec, on observe une mortalité de $50 \%$ au bout de $24 \mathrm{~h}$. Selon les résultats de l'étude ET, l'application directe d'une goutte de $10 \mu \mathrm{L}$ de Success est extrêmement toxique pour les abeilles et la mortalité est de $100 \%$ après $12 \mathrm{~h}$

Les abeilles peuvent butiner dans un champ pendant une demi-heure ou plus et le nombre de voyages entre la ruche et le champ peut atteindre 10 par jour (Gary, 1992). Dans notre étude, lorsque Success a séché durant $6 \mathrm{~h}$ et que les abeilles ont été exposées durant $3 \mathrm{~h}$, la mortalité est de $50 \%$ après $24 \mathrm{~h}$. Les abeilles peuvent donc être confrontées à une exposition cumulée de plusieurs heures à Success au cours d'une période de butinage de $24 \mathrm{~h}$ et en mourir. Il est nécessaire de poursuivre des recherches sur les effets toxiques pour les abeilles d'une pulvérisation de Success durant toute une saison et sur l'impact possible de $V$. destructor et des maladies.

\section{Apis mellifera / Ceratitis capitata / spinosad / insecticide / toxicité / apiculture}

\section{Zusammenfassung - Eine Laborstudie zur} Bestimmung der Toxizität des Köders Success 0.02 CB der mediterranen Fruchtfliegen Ceratitis capitata für Honigbienen Apis mellifera. Weltweit ist die mediterrane Fruchtfliege Ceratitis capitata (Wiedemann), eine der zerstörerischsten Schädlinge für Obst und Gemüseernten. Wegen des Potentials für Ernteschäden durch diesen Schädling hat die Abteilung der Landwirtschaft der Vereinigten Staaten (USDA) und der Gesundheitsdienst für Tiere und Pflanzen (APHIS), in Zusammenarbeit mit den Regierungen Mexiko und Guatemala, ein umfassendes Programm zur Ausrottung der Fruchtfliege durchgeführt. Success $0.02 \mathrm{CB}^{\mathrm{TM}}$ (GF-120), eine Kombination von Spinosad mit Ammoniumazetat, ein die Fruchtfliege anlockendes und die Honigbiene abweisendes Gift, wird zur Zeit am häufigsten in Ausrottungsprogrammen der Fruchtfliege benutzt. Guatemala betreibt eine erfolgreiche Agrarindustrie. Etwa seit Beginn des Programms zur Ausrottung der Fruchtfliege beklagten Imker in Gebieten, in denen Success gesprüht wurde, einen Rückgang der Zahl der Honigbienen, verbunden mit einem allgemeinen Rückgang der Honigernte. Mehrere Wissenschaftler glauben, dass nicht Success die Ursache ist, sondern dass die Verluste durch die Varroa Milben (Varroa destructor) und andere Bienenkrankheiten entstanden sind. Deshalb 
sollte mit Laboruntersuchungen geklärt werden, ob das gegen die Fruchtfliegen angewendete Success Honigbienen vernichten kann.

Honigbienen wurden einer Dauerbehandlung, einer begrenzten und einer topikalen Behandlung mit Success Rückständen unter Laborbedingungen an der Purdue Universität, West Lafayette, Indiana, USA in 2001 ausgesetzt. Um eine natürliche Mortalität durch Verhungern $\mathrm{zu}$ vermindern, wurden ein Schwamm mit einer $50 \%$ Sucrose Lösung in jedes Testgefäß gegeben. Während der Dauerbehandlung hatten die Bienen mit einem $15 \mu \mathrm{L}$ Tropfen von nassen oder trockenen Rückständen mit einem $1 \times$ oder $10 \times$ Success Anteil Kontakt (Rückstände wurden 6-24 Stunden getrocknet). Die Mortalität wurde 6, 12, und 24 Stunden nach ihrer Exposition gemessen. Während der begrenzten Behandlung wurden Bienen einem $15 \mu \mathrm{L}$ Tropfen mit trockenen oder feuchten Rückständen (Rückstände für 6 Stunden getrocknet) und einem $1 \times$ Anteil von Success oder einem $95 \%$ malathion+Nu-Köder ausgesetzt. Nach dieser 1 bis 3 stündigen Behandlung wurden die Honigbienen in eine nicht kontaminierte Petrischale umgesetzt und ihre Mortalität 1, 6, 12, und 24 Stunden nach der Umsetzung bestimmt. Bei der topikalen Behandlung wurde ein $10 \mu \mathrm{L}$ Tropfen in $1 \times$ oder $0.1 \times$ Raten aus Success oder $95 \%$ malathion+Nu-Köder oder $50 \%$ Zuckerlösung direkt auf die Honigbienen gegeben. Die Mortalität wurde 1, 3, 6, und 12 Stunden später bestimmt.

Die Dauerbehandlung ergab, dass nach einer einmaligen Success Behandlung mit 3 Stunden lang getrocknetem Success und einer Behandlungsdauer von 6 Stunden, die Behandlung für 43,8 \% der Bienensterblichkeit verantwortlich war. Nach einer Trocknung des Mittels für 24 Stunden starben nur 4,2 \% der Bienen nach einer 6 stündigen Behandlung; nach einer Kontamination von 24 Stunden jedoch verursachte sie den Tod von $62,5 \%$ der Bienen. In der Untersuchung mit begrenzten Behandlungszeiten bei einer Exposition der Bienen von nicht mehr als einer Stunde zum Success $1 \times$ Anteil nach Trocknung wurde im Vergleich zur Kontrolle 12 Stunden nach Umsetzen in ein sauberes Gefäß kein Unterschied in der Bienensterblichkeit beobachtet. Wurden sie jedoch 3 Stunden dem getrockneten Rückstand ausgesetzt, ergab sich nach 24 Stunden eine Sterblichkeit von $50 \%$. Bei der topikalen Behandlung, also einer direkten Applikation von einem $10 \mu \mathrm{L}$ Tropfen Success auf Honigbienen, erwies sich das Mittel als hoch toxisch und nach 12 Stunden betrug die Mortalität $100 \%$.

Honigbienen können eine halbe Stunde oder mehr im Freien sammeln und die Zahl der Ausflüge kann bis zu 10 am Tag betragen (Gary, 1992). In unserer Untersuchung starben $50 \%$ der Bienen innerhalb von 24 Stunden, wenn sie Success, das 6 Stunden lang trocknen konnte, 3 Stunden lang ausgesetzt waren. Deshalb könnten Bienen, deren Trachtgebiet mit Success behandelt worden ist, innerhalb von 24
Stunden sterben. Weitere Untersuchungen über die toxische Wirkung des Sprühens von Success auf Honigbienen während einer ganzen Saison zur Vernichtung der Fruchtfliegen einerseits und der mögliche Effekt von Varroa Milben und anderer Krankheiten der Bienen andererseits sind notwendig.

\section{Bienenhaltung / Apis mellifera / Ceratitis capitata / Spinosad / Success 0.02 CB}

\section{REFERENCES}

Burns R.E., Harris D.L., Moreno D.S., Eger J.E. (2001) Efficacy of spinosad bait sprays to control Mediterranean and Caribbean fruit flies (Diptera: Tephritidae) in commercial citrus in Florida, Fla. Entomol. 84, 672-678.

Cohen E., Podoler H., El-Hamlauwi M. (1987) Effects of the malathion-bait mixture used on citrus to control Ceratitis capitata (Wiedemann) (Diptera: Tephritidae) on the Florida red scale, Chrysomphalus aonidum (L.) (Hemiptera: Diaspididae), and its parasitoid Aphytis holoxanthus DeBach (Hymenoptera: Aphelinidae), Bull. Entomol. Res. 77, 303-307.

Daane K.M., Dahlsten D.L., Dreistadt S.H. (1990) Effects of Mediterranean fruit fly malathion bait spray on the longevity and oviposition of parasitoids of linden and tuliptree aphids (Homoptera: Aphididae), Environ. Entomol. 19, 1130-1134

Dow AgroSciences (2001) Spinosad technical bulletin, Dow AgroSciences, Indianapolis, IN.

Ehler L.E., Endicott P.C., Hertlein M.B., AlvaradoRodriquez B. (1984) Medfly eradication in California: Impact of malathion-bait sprays on an endemic gall midge and its parasitoids, Entomol. Exp. Appl. 36, 201-208.

el Periódico, Guatemala (January 16, 2002), No. 1855 , p. 2.

Epsky N.D., Hendrichs J., Katsoyannos B.I., Vásquex L.A., Ros J.P., Zümreoglu A., Pereira R., Bakri A., Seewooruthun S.I., Heath R.R. (1999) Field evaluation of female-targeted trapping systems for Ceratitis capitata (Diptera: Tephritidae) in seven countries, J. Econ. Entomol. 92, 156-164.

Gary N.E., Mussen E.C. (1984) Impact of Mediterranean fruit fly malathion bait spray on honey bees, Environ. Entomol. 13, 711-717.

Gary N.E. (1992) Activities and behavior of honey bees, in: Graham J.M. (Ed.), The Hive and the Honey Bee, Dadant and Sons, Hamilton, Illinois, pp. 269-361.

Heath R.R., Epsky N.D., Dueben B.D., Rizzo J., Jeronimo F. (1997) Adding methyl-substituted ammonia derivatives to a food-based synthetic attractant on capture of the Mediterranean and Mexican fruit flies (Diptera: Tephritidae), J. Econ. Entomol. 90, 1584-1589. 
Hoelmer K.A., Dahlsten D.L. (1993) Effects of malathion bait spray on Aleyrodes spiraeoides (Homoptera: Aleyrodidae) and its parasitoids in northern California, Environ. Entomol. 22, 49-56.

Hoy J.B., Dahlsten D.L. (1984) Effects of malathion and Staley's bait on the behavior and survival of parasitic Hymenoptera, Environ. Entomol. 13, 1483-1486.

Katsoyannos B.I., Heath R.R., Papadopoulos N.T., Epsky N.D., Hendrichs J. (1999) Field evaluation of Mediterranean fruit fly (Diptera: Tephritidae) female selective attractants for use in monitoring programs, J. Econ. Entomol. 92, 583-589.

Levin M.D., Forsyth W.B., Fairbrother G.L., Skinner F.B. (1968) Impact of colonies of honey bees of ultra-low-volume (undiluted) malathion applied for control of grasshoppers, J. Econ. Entomol. 61, $58-62$.

Liquido N.J., Shinoda L.A., Cunningham R.T. (1991) Host plants of Mediterranean fruit fly: An annotated world review, Misc. Publ. Entomol. Soc. Am. 77, 1-52.

Pankiw T., Jay S.C. (1992) Aerially applied ultralow-volume malathion effects on caged honey bees (Hymenoptera: Apidae), caged mosquitoes (Diptera: Culicidae), and malathion residues, J. Econ. Entomol. 85, 687-691.

Peck S.L., McQuate G.T. (2000) Field tests of environmentally friendly malathion replacements to suppress wild Mediterranean fruit fly (Diptera: Tephritidae) populations, J. Econ. Entomol. 93, 280-289.

Phillips P. (1995) California red scale: The recovery of biological controls after an aerial bait spray program for Medfly eradication, Cal. Grower: Avocados, Citrus, Subtropicals 19, 44-46.
Prensa Libre, Guatemala (February 12, 2001).

Rendon P.A., Jeronimo F., Ibarra J., Alvarez V.C. (2000) Effectiveness of Success $0.02 \mathrm{CB}^{\mathrm{TM}}$ for the control of fruit flies and its effect on bees, Apis mellifera L. USDA, APHIS, PPQ, Methods Development Station, Guatemala.

Roubik D.W. (2002) The value of bees to the coffee harvest, Nature 417, 708.

Steiner L.F., Rohwer G.G., Ayers E.L., Christenson L.D. (1961) The role of attractants in the recent Mediterranean fruit fly eradication program in Florida, J. Econ. Entomol. 54, 30-35.

SuperANOVA (1989) Superanova: Accessible general linear modeling. Abacus Concepts, Inc. Berkeley, CA.

US Department of Agriculture, Animal and Plant Health Inspection Service (1999) Plant protection and quarantine fact sheet: The Mediterranean fruit fly. USDA, APHIS, Riverdale, MD.

US Department of Agriculture, Animal and Plant Health Inspection Service (2001) Spinosad for the Moscamed Program, Environmental Analysis 2001, USDA, APHIS, Riverdale, MD.

Vargas R.I., Peck S.L., McQuate G.T., Jackson C.G., Stark J.D., Armstrong J.W. (2001) Potential for areawide integrated management of Mediterranean fruit fly (Diptera: Tephritidae) with a braconid parasitoid and a novel bait spray, J. Econ. Entomol. 94, 817-825.

Villaseñor A., Carrillo J., Zavala J., Stewart J., Lira C., Reyes J. (2000) Current progress in the Medfly Program Mexico-Guatemala, in: KengHong Tan (Ed.), Area-Wide Control of Fruit Flies and Other Insect Pests, Penerbit Universiti Sains Malaysia, pp. 361-368. 